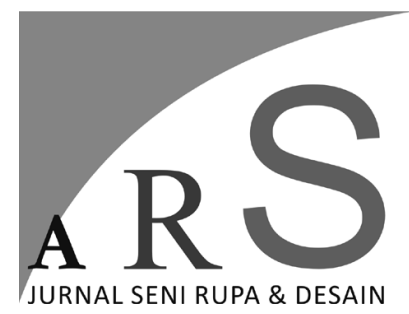

Volume 22 Nomor 1 - April 2019

\section{ANALISIS WACANA KRITIS IKLAN FILM PENDEK LINE VERSI “ADA APA DENGAN CINTA?”}

\author{
Pranan Sutiono Saputra \\ Program Studi Desain Komunikasi Visual, Jurusan Desain \\ Fakultas Seni Rupa, Institut Seni Indonesia Yogyakarta
}

\begin{abstract}
ABSTRAK
Tujuan penelitian ini adalah untuk membongkar wacana yang terkandung di dalam iklan Ada Apa Dengan Cinta? tersebut yang menyebabkan viral di kalangan warganet. Melalui penelitian ini wacana yang terkandung di dalam iklan tersebut diuraikan dengan menggunakan metode analisis wacana kritis yang bersifat kualitatif yang dikembangkan oleh Norman Fairclough. Merujuk pada pendekatan tersebut, iklan sebagai objek penelitian akan diuraikan ke dalam tiga tingkatan analisis, yaitu dimensi teks, praktik kewacanaan, dan praktik sosiokultural. Pada tahap dimensi teks, dilakukan analisis unsur representasi, relasi, dan identitas. Melalui analisis pada dimensi teks dapat dipahami bahwa nostalgia direpresentasikan melalui relasi antara tokoh dengan objek di dalam iklan maupun dengan khalayak. Kemudian pada tahap dimensi praktik kewacanaan, dilakukan analisis unsur produksi dan konsumi. Pada dimensi praktik kewacanaan terjadi proses komodifikasi ingatan atau nostalgia antara Line dan Miles Production dengan khalayak. Selanjutnya, tahap terakhir, yaitu analisis unsur situasional, institusional, dan sosial pada dimensi praktik sosiokultural. Analisis pada dimensi praktik sosiokultural menunjukkan bahwa pengadaptasian film Ada Apa dengan Cinta? (2002) didasarkan pada kepentingan-kepentingan kelompok tertentu. Hasil penelitian menunjukkan bahwa dalam iklan tersebut banyak terkandung wacana yang sengaja dikonstruksikan. Salah satunya, yaitu wacana nostalgia melalui pengadaptasian film Ada Apa dengan Cinta? (2002). Dalam iklan ini, nostalgia diposisikan sebagai komoditas. Nostalgia hanyalah satu dari sekian banyaknya wacana yang dikonstruksikan di dalam iklan yang pada akhirnya seluruh wacana akan bermuara pada kepentingan ekonomi kapitalis. Pengadaptasian tersebut dipandang sebagai upaya yang dilakukan Line untuk meminimalisir kegagalan promosi karena penggemar franchise film Ada Apa Dengan Cinta? (2002) yang berumur 27-37 tahun pada 2014 masih ada dan jumlahnya cukup besar. Selain itu, pemilihan Youtube sebagai media penayangan, dampak masifnya respon khalayak yang berupa pemberitaan media, meme, video parodi, bandwagon effects, akan memberikan keuntungan yang besar bagi Line dan Miles Production.
\end{abstract}

Kata kunci: Line, Ada Apa Dengan Cinta?, Youtube, analisis wacana kritis 


\begin{abstract}
The method of data analysis used in this research is Critical Discourse Analysis, with qualitative manner that was found by Norman Fairclough. The analysis went through three dimensions, which are text, the practice of discourse, and the practice of sociocultural. In the part of text dimension, analysis of representation, relation, and identity was done. Then, in the part of practical discourse dimension, analysis of parts of production and consumption were done. After dimensions of text and practical discourse were done, last part was situational, institutional, and social part analysis as part of sociocultural practice dimension. The result of the research showed that in that advertisements appeared plenty of discourse that was purposely made. One of them was nostalgic discourse with the adaptation of Ada Apa dengan Cinta? (2002) movie. In this advertisement, nostalgia was used as commodity. Nostalgia will only be one of many discourse constructed in advertisement, in which all the discourses will end up to the purpose of capitalist economy. That adaptation was seen as an attempt by LINE to minimize the failure of advertisement, for the fans of Ada Apa dengan Cinta? Movie was stable and large. Beside that, the usage of YouTube as media to show video, the effect became massive to the people, who used media news, meme, parody video, bandwagon effects, will give great benefit to LINE and Miles Production.
\end{abstract}

Keywords: Line, Ada Apa Dengan Cinta?, Youtube, Critical Discourse Analysis

\section{Pendahuluan}

Melimpahnya media yang ada, khususnya media baru dipandang sebagai peluang oleh produsen atau para pengiklan untuk mengiklankan produk mereka dari segala penjuru lini media. Selain itu, bentuk iklan pun mengalami banyak perubahan dan semakin beragam. Salah satunya, iklan audio visual yang merupakan salah satu produk desain komunikasi visual yang berubah tak hanya terbatas pada format video yang sudah ada, melainkan formatnya jauh lebih beragam.

Fungsi-fungsi media tradisional sebelumnya dapat dipenuhi dengan media baru. Misalnya, situs jejaring berbagi video, Youtube yang memberikan alternatif pilihan untuk menyaksikan tayangan audio visual yang tak kalah menarik dengan program di televisi. Tak hanya itu, waktu yang disediakan, sumber tanpa batas, dan bisa diakses kapan dan di mana saja, menyebabkan kehadiran internet termasuk media-media di dalamnya, seperti media sosial, menjadi lebih dominan. Tak ayal, situasi ini pun mendorong banyak perusahaan untuk menggunakan media sosial untuk mengiklankan produk mereka.

Salah satu iklan produk yang menyita perhatian banyak kalangan warganet, yaitu iklan Line versi Ada Apa dengan Cinta? 2014 yang muncul di akhir 2014. Iklan ini melanjutkan kisah Cinta dan Rangga dari film blockbuster Ada Apa dengan Cinta? yang booming di tahun 2002. Tak pelak, iklan ini tentu sarat dengan upaya pemenuhan hasrat kembali ke masa lalu atau nostalgia. Apalagi banyak adegan dari iklan ini yang merepresentasikan nostalgia baik secara reflektif maupun rekonstruktif. Selain itu, dalam beberapa tahun terakhir penggunaan nostalgia sebagai ide dalam perwujudan media terbilang cukup banyak, misalnya munculnya kembali film Star Wars, banyaknya film remake, live action, tayangan serial drama era 90 -an yang dimunculkan kembali di televisi, produk Indomie dengan kemasan jadul, dan sebagainya.

Iklan ini hadir dengan format periklanan baru, yaitu iklan film pendek (short film advertising) yang muncul pertama kali di Youtube pada tahun 2014 dengan menawarkan produk Nike bertajuk The Last Game yang meraih 79 juta viewer. Dalam artikel "ShapeShifter: Are Short Films the Future of Advertising?", diulas tentang film pendek ShapeShifter yang dianggap sebagai bentuk iklan masa depan. Selain itu, dikatakan iklan semacam ini melakukan pendekatan secara halus dan elegan sehingga lebih disukai oleh audiens. (Eisenberg, 2011)

Iklan dengan format semacam ini sudah diadaptasi oleh cukup banyak perusahaan 
Indonesia untuk mengiklankan produk mereka, tetapi sebagian besar iklan tersebut tidak mampu menarik perhatian dan menjadi buah bibir khalayak luas. Dalam waktu sepuluh hari penayangan, iklan Line versi Ada Apa dengan Cinta? 2014 berhasil mencatat 3,8 juta penayangan di Youtube, pengguna Line meningkat hingga 170 juta akun $(700 \%)$ terhitung sampai dengan Oktober 2014, dan 180.200 sekolah telah terdaftar di Line. (Perdana, 2015) Bahkan setelah menjadi viral/buah bibir di kalangan warganet, banyak kalangan dan perusahaan besar yang memanfaatkannya dengan membuat meme, video parodi, bandwagon branding, dan sebagainya. Setahun setelahnya, Mira Lesmana melalui akun Twitter-nya mengungumkan bahwa film Ada Apa dengan Cinta? akan dibuat sekuel atau kelanjutannya karena melihat respon masyarakat yang sangat antusias dengan iklan AADC? 2014. Oleh karena itu, berdasarkan fenomenafenomena yang ada dan melalui pendekatan analisis wacana kritis, penelitian ini bertujuan untuk menguraikan bagaimana wacana nostalgia dikonstruksi dalam iklan film pendek Line versi Ada Apa dengan Cinta? 2014.

\section{Analisis Wacana Kritis Norman Fairclough}

Wacana dapat diartikan sebagai pesan yang memuat realitas yang telah dikonstruksikan dengan sistem tanda sebagai alat utamanya dan dipengaruhi oleh struktur sosial yang ada melalui bahasa. Praktik sosial menjadi poin penting dalam analisis wacana kritis model Norman Fairclough. Wacana sebagai praktik sosial dalam bentuk interaksi simbolis dapat terungkap dalam sebuah pembicaraan, tulisan, gambar, diagram, foto, film, iklan, musik, atau berbagai sumber media lain.

Menurut Norman (Fairclough, 1995) yang dimaksud dengan analisis wacana kritis adalah analisis wacana yang bertujuan untuk (a) mengeksplorasi secara sistematis hubungan antara kausalitas dan determinasi di antara praktekpraktek diskursif, kejadian-kejadian dan teks; (b) struktur sosial yang lebih luas dan struktur budaya, relasi, dan proses; (c) untuk menginvestigasi bagaimana praktek-praktek, kejadian, dan teks berkembang diluar dan secara ideologis dibentuk oleh relasi kekuatan dan bertahan dari kekuasaan; dan (d) untuk mengeksplorasi bagaimana opasitas hubungan antara wacana dan masyarakat sendiri adalah sebuah faktor mengamankan kekuasaan dan hegemoni. Analisis wacana kritis terfokus pada dua hal, yaitu praktik-praktik diskursif yang menciptakan representasi tentang dunia subjeksubjek serta relasi-relasi sosialnya, dan peran dari praktik-praktik diskursif ini untuk memapankan dan melestarikan kepentingan politik kelompokkelompok sosial tertentu.

Fairclough membagi analisis wacana dalam tiga dimensi: teks, discource practice, dan sociocultural practice. (Eriyanto, 2011) Proses produksi dan pengonstruksian wacana tentu dipengaruhi oleh teks. Proses analisis pada dimensi teks dilakukan dengan mendeskripsikan apa yang direpresentasikan, direlasikan, dan diidentifikasikan di dalam iklan. Secara sistematis, pada tahap pertama dilakukan analisis pada aspek representasi, yaitu dengan menguraikan makna yang ada dalam iklan berdasarkan realitas sosial yang ada ke dalam bentuk deskripsi.

Selanjutnya, pada tahap kedua dilakukan analisis pada aspek relasi, yaitu dengan menguraikan hubungan antar produsen iklan (Line dan Miles Production), khalayak, partisipan media, dan partisipan publik yang ditampilkan dalam iklan. Terakhir, analisis dilakukan pada identitas produsen iklan (Line dan Miles Production), khalayak, dan partisipan publik yang ditampilkan dalam teks. Ini terkait erat dengan upaya yang dilakukan dalam penyampaian citra perusahaan kepada khalayak.

Proses analisis pada dimensi praktik kewacanaan dilakukan dengan menginterpretasikan bagaimana proses produksi dan konsumsi teks dan wacana dalam iklan. Pada proses produksi terjadi proses pengonstruksian wacana yang ada dalam iklan. Selain wacana, biasanya pada proses produksi terjadi proses komodifikasi. Selanjutnya, dalam proses konsumsi, iklan berubah menjadi produsen dan yang diproduksinya adalah khalayak untuk dikomodifikasi kembali. Khalayak yang tadinya komoditas kemudian menjadi produsen makna dan kepuasan yang dapat dilihat melalui komentar atau respon yang ada pada kolom komentar, like, dislike, jumlah penayangan, dan share.

Pada dimensi praktik sosiokultural, proses analisis dilakukan dengan penjelasan (eksplanasi) 
hubungan antara proses wacana pada dimensi praktik kewacanaan dengan proses sosial yang terjadi di dalam masyarakat. Analisis praktik sosiokultural dilakukan dengan tiga tingkat, yaitu situasional, institusional, dan sosial. Pada tingkat situasional, analisis diakukan dengan melibatkan pengaruh aspek waktu dan suasana saat iklan diluncurkan (konteks peristiwa). Selanjutnya, analisis dilakukan pada pengaruh institusi, baik dari dalam media maupun kekuatan-kekuatan eksternal. Terakhir, analisis aspek sosial dilakukan dengan menguraikan mengapa perubahan sosial di masyarakat mempengaruhi wacana yang muncul dalam iklan. Apabila pada analisis aspek situasional lebih mengarah pada konteks peristiwa yang bersifat mikro, aspek sosial lebih melihat pada aspek makro seperti sistem politik, ekonomi, maupun budaya secara keseluruhan.

\section{Hasil Penelitian}

Dari total keseluruhan scene yang ada pada iklan tersebut, hanya enam scene yang diambil sebagai sampel penelitian. Keenam scene tersebut dipilih karena memenuhi kriteria dan cukup relevan dengan topik pembahasan mengenai wacana nostalgia, yaitu scene 14, 20, 49, 51, 60, dan 62. Namun, tidak menutup kemungkinan, penelitian ini masih akan melibatkan scene-scene lainnya karena adanya keterhubungan antar scene yang terkait erat dengan pemaknaan secara utuh.

\section{Dimensi Teks \\ Representasi}

Analisis pertama dilakukan pada tahap dimensi teks dengan menampilkan makna yang direpresentasikan di dalam iklan. Dari keenam scene yang diambil sebagai unit analisis, terdapat

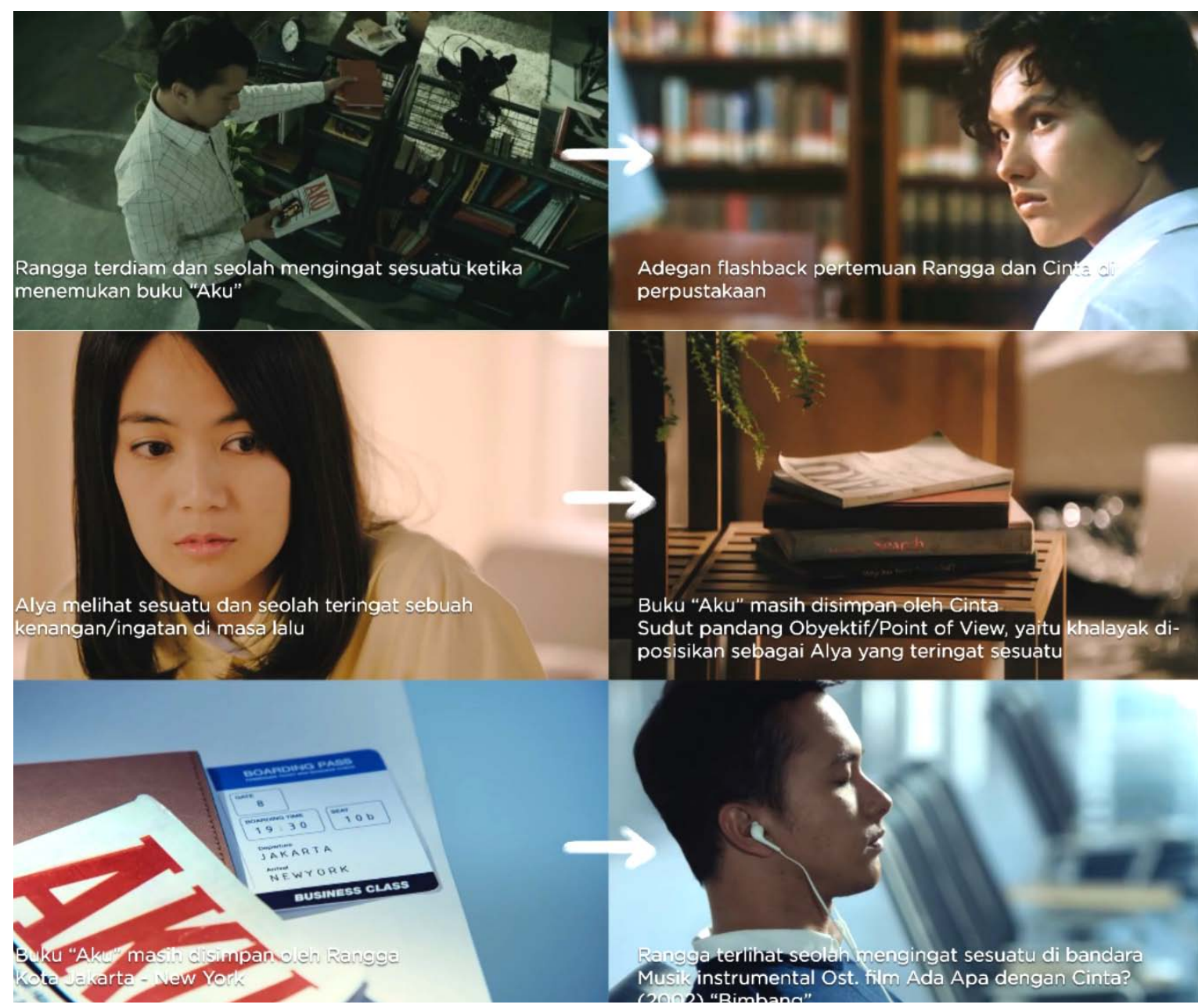

Gambar 1. Adegan represif merepresentasikan nostalgia. (Sumber: Dok. Pranan S. Saputra). 
tiga praktik represif yang menampilkan buku kumpulan puisi Chairil Anwar karya Sjuman Djaya yang berjudul "Aku", yaitu pada scene 14, 51, dan 60. Pertama, interaksi Rangga dengan buku "Aku" yang tidak sengaja dia jatuhkan dan membawanya ke memori masa lalu diikuti dengan adegan flashback. Kedua, interaksi Alya dengan buku "Aku" yang berada di tumpukan paling atas di atas meja di rumah Cinta. Ketiga, interaksi buku "Aku" dengan Boarding Pass yang tertulis tujuan kota New York dengan keberangkatan dari kota Jakarta.

Ketiga interaksi tersebut merepresentasikan bahwa tokoh atau benda yang berinteraksi tersebut memiliki relasi dengan masa lalu. Ini diperlihatkan dengan ekspresi Rangga dan Alya yang memandang buku "Aku" seolah tengah mengingat suatu kenangan yang berharga. Selanjutnya, melalui adegan Cinta yang termenung memikirkan Rangga pada sebagian besar scene menggambarkan bahwa Cinta masih belum bisa melupakan kenangannya bersama dengan Rangga yang dulunya merupakan kekasihnya di bangku SMA.

Selain buku "Aku", simbol nostalgia juga dimunculkan melalui ikon-ikon film Ada Apa dengan Cinta? (2002), antara lain musik dan lagu "Bimbang”, tokoh Rangga, Cinta, Karmen,
Milly, Maura, dan Alya, adegan perpisahan di bandara, relasi New York - Jakarta, adegan flashback, dan kata "satu purnama". Simbolsimbol tersebut ditampilkan dalam iklan secara reflektif maupun rekonstruktif. Selanjutnya, merujuk pada komunikasi verbal yang digunakan dalam iklan tersebut ditemukan beberapa atribut nostalgia, yaitu kata "dua belas tahun", "mulai dari awal", "beda satu purnama", "detik", "waktu", "hari", "terulang", "pagi" dan "belum sempat". Atribut tersebut terdapat pada tiga dialog dan monolog yang termasuk dalam unit analisis. Oleh karena itu, apabila diperhatikan dari dialog dan monolog yang ditampilkan, iklan tersebut banyak menceritakan persoalan waktu yang erat kaitannya dengan kenangan dan nostalgia.

\section{Relasi}

Pada tahap relasi, hubungan dikonstruksi di antara khalayak dan kekuatan sosial yang mendominasi. Kelompok masyarakat yang berkedudukan tinggi, umumnya ditempatkan lebih tinggi dalam relasi dengan Line. Iklan tersebut menyampaikan kepada khalayak bahwa khalayak tunduk pada sistem aplikasi Line. Bahkan, melalui kesediaan khalayak menonton iklan tersebut sampai selesai menjadi bukti di mana khalayak berada di bawah kendali Line. Hubungan antara

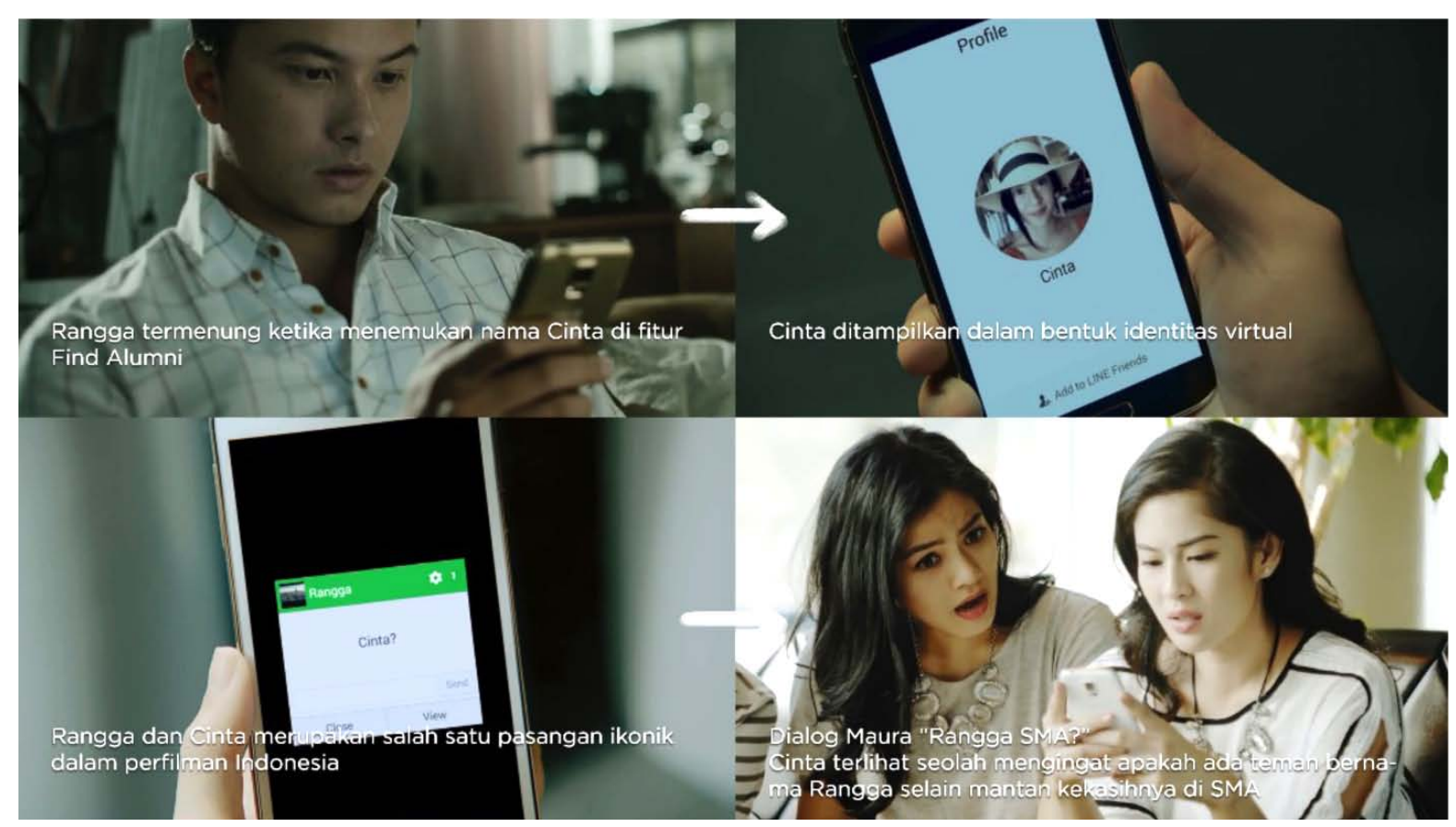

Gb. 2. Adegan yang menunjukkan Line bertindak sebagai medium nostalgia.

(Sumber: Dok. Pranan S. Saputra) 
Line dengan khalayak yang demikian dipahami sebagai salah satu bentuk relasi kekuasaan.

Tak hanya itu, relasi kekuasaan juga ditunjukkan pada adegan pelenyapan media lain, keberpihakan pada gaya hidup kelas atas, dan keberpihakan pada nostalgia film Ada Apa dengan Cinta? (2002). Selain relasi kekuasaan, antara Line dengan khalayak terjalin relasi penjual-pembeli. Line menjual makna yang sarat akan konstruksi melalui iklan. Sedangkan, khalayak membelinya dengan uang dan waktu. Selain itu, melalui ending cerita iklan tersebut dapat dipahami bahwa Line memposisikan dirinya sebagai pihak yang menghubungkan kembali kisah yang menggantung dan menjadi jawaban atas segala pertanyaan yang ada pada benak khalayak. Secara singkat, Line memberikan kebahagiaan bagi keduanya yang merupakan representasi dari konsumen. Pengadaptasian film Ada Apa dengan Cinta? (2002) pun dipahami sebagai upaya Line memberikan kepuasan pengalaman bagi khalayak. Secara singkat, selain Line sebagai medium komunikasi, Line juga bertindak sebagai medium nostalgia.

\section{Identitas}

Melalui iklan tersebut ditampilkan identitas nostalgia dari film Ada Apa dengan Cinta? (2002) melalui musik "Bimbang" sebagai original soundtrack film karya Melly Goeslaw pada scene 20, 60, dan 62, buku kumpulan puisi Chairil Anwar karya Sjuman Djaya yang berjudul "Aku", tokoh Cinta dan Rangga, dan ungkapan "satu purnama”. Sedangkan identitas Miles Production dimunculkan dengan franchise film Ada Apa dengan Cinta? (2002) berupa kisah percintaan Cinta dan Rangga, termasuk di dalamnya tokohtokoh lainnya beserta kisah ceritanya. Ini terjadi karena film Ada Apa dengan Cinta? (2002) sendiri merupakan film besutan Rudi Soedjarwo dengan cerita yang ditulis oleh Mira Lesmana. Film yang lekat dengan Miles Production ini dianggap sebagai tonggak kebangkitan perfilman Indonesia. Tak hanya itu, film ini berhasil melambungkan nama pemeran tokoh-tokohnya dan segenap kru yang terlibat di bawah payung Miles Production.

\section{Dimensi Praktik Kewacanaan \\ Produksi}

Nostalgia di dalam iklan ini dikonstruksikan sebagai komoditas bernilai guna. Selain dipahami sebagai komodifikasi ingatan, dalam iklan ini nostalgia juga dipahami sebgai bentuk komodifikasi isi pesan. Ingatan khalayak tentang film Ada Apa dengan Cinta? (2002) diperlakukan sebagai komoditas. Selain komodifikasi isi pesan, melalui penayangan iklan ini di Youtube dipahami sebagai komodifikasi khalayak, di mana khalayak diperjualbelikan antara Line, Miles Production, dan Youtube.

Iklan tersebut sesungguhnya tidak hanya ditujukan untuk menjawab rasa penasaran anak muda Indonesia tentang kelanjutan kisah asmara Rangga dan Cinta, tetapi juga menawarkan solusi. Adapun solusi yang ditawarkan, yaitu menjawab kegelisahan khalayak terhadap masa depan dengan harapan semu dan kerinduan masa lalu dalam satu waktu, di mana iklan menjadi penghubung kedua waktu itu. Sebagaimana yang diungkapkan oleh Williamson (2007: 244), sebuah gambar dapat merepresentasikan bukan hanya sebuah peristiwa, melainkan juga serangkaian peristiwa, dan iklan-iklan yang membangkitkan masa lalu, menjanjikan masa depan, atau menceritakan suatu kisah yang meliputi baik masa lalu maupun masa depan.

Pengadaptasian film Ada Apa dengan Cinta? (2002) tidak semata-mata hanya persoalan relevansi, melainkan lebih dari itu. Tak dapat dipungkiri rasa cinta merupakan hal yang sangat dekat dengan kehidupan bersosial masyarakat. Bahkan, agama apapun mengajarkan pentingnya cinta kasih kepada sesama. Cinta layaknya oase di tengah beban hidup berat yang harus dijalani setiap harinya sehingga khalayak menjadikan rasa cinta itu sebagai penawar dahaga yang memabukkan. Tak pelak, rasa cinta itu dipenuhi dengan berbagai cara, salah satunya dengan hiburan berupa film.

Selanjutnya, berdasarkan diagram rentang umur khalayak dengan mempertimbangkan klasifikasi rentang umur berdasarkan Depkes RI tahun 2009 dan khalayak film Ada Apa dengan Cinta? (2002), diperoleh bahwa khalayak yang disasar dalam iklan ini merupakan khalayak yang tumbuh bersama film Ada Apa dengan Cinta? 


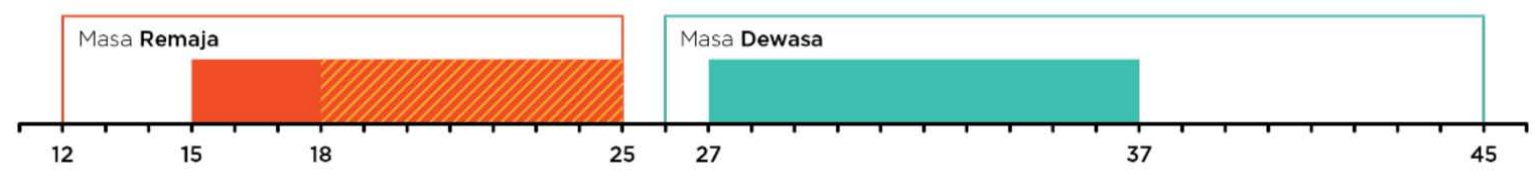

Audiens Ada Apa dengan Cinta? 2002 (15-25 tahun) Sumber: Koran Bisnis Indonesia, kalimantan.bisnis.com, 16/12/2004

Audiens Dominan Aplikasi Line (18-25 tahun) Sumber: tempo.co, 21/02/2017

Audiens Iklan Line Versi Ada Apa dengan Cinta? 2014

Diperoleh dari $2014-2002=12$ tahun $15+12=27$ tahun, $25+12=37$ tahun

Sehingga, diperkirakan target audiens berumur 27 - 37 tahun

Gb. 3. Diagram perkiraan rentang umur audiens (Sumber: Dok. Pranan S. Saputra)

(2002) dan pada tahun 2014 telah termasuk ke dalam kelompok usia dewasa muda (27-37 tahun). Tentunya pada rentang usia tersebut khalayak yang disasar telah lulus menempuh pendidikan dengan asumsi bahwa apabila target khalayak film Ada Apa dengan Cinta? (2002) termasuk kategori remaja (15-25 tahun) berarti tengah menempuh pendidikan tingkat SMP, SMA, atau pendidikan tinggi pada tahun 2002 dan telah bekerja pada tahun 2011 .

Khalayak dewasa muda yang digambarkan telah bekerja, tentu dirasa jauh lebih prospektif atau membutuhkan dari pada audiens muda yang masih sekolah. Ini dikarenakan khalayak tersebut telah menyelesaikan pendidikan sampai ke jenjang yang tinggi sehingga jangkauan pencarian teman lamanya tidak hanya sebatas teman masa SD, SMP, SMA, tetapi juga pendidikan tinggi. Pengadaptasian ini juga tentu bertujuan untuk merangkul penggemar franchise film Ada Apa dengan Cinta? (2002) termasuk para penggemar aktor dan aktris yang terlibat di dalamnya. Ini dilakukan untuk meminimalisir risiko kegagalan produk di pasar. Dengan kata lain, iklan tersebut mengincar penggemar setia dan kesetiannya terhadap franchise film Ada Apa dengan Cinta? (2002). Bagaimanapun loyalitas konsumen sangatlah penting bagi eksistensi sebuah produk.

\section{Konsumsi}

Banyak khalayak yang mempertanyakan alasan Rangga tidak mencoba menghubungi Cinta dengan menggunakan Facebook, di mana Facebook memiliki fitur pencarian yang baik dalam menemukan orang yang ingin dicari.
Pelenyapan atas aplikasi media sosial lainnya termasuk Facebook merupakan salah satu bentuk upaya yang dilakukan untuk mengonstruksikan aplikasi Line sebagai satu-satunya aplikasi yang dapat memenuhi kebutuhan khalayak.

Dari keseluruhan komentar yang ada, sebagian besar audiens menuliskan hal-hal yang diingat semasa dulu ketika film Ada Apa dengan Cinta? muncul di tahun 2002. Selain film Ada Apa dengan Cinta? (2002) yang diingat, terdapat beberapa audiens yang berkomentar mengenai iklan tersebut mengingatkan mereka ke kenangan semasa duduk di bangku sekolah, khususnya masa-masa SMA. Bahkan menurut salah satu akun di kolom komentar, euforia film Ada Apa dengan Cinta? (2002) telah memunculkan tren di kalangan anak muda pada saat itu.

\section{Dimensi Praktik Sosiokultural Situasional}

Dengan adanya Pilpres 2014 dan TV yang sesak dengan indikasi kekerasan dan seksual mendorong masyarakat yang merasa sudah susah dan lelah akan cenderung mencari hiburan yang ceritanya gampang diikuti dari pada film-film yang mengajak mereka berpikir. Karena itu, yang laku adalah drama percintaan atau film action yang melahirkan para hero yang menang dan orang jahat yang jadi pecundang. (Ibrahim, 2007:178) Mengusung drama percintaan dengan melanjutkan kisah Cinta dan Rangga dari film Ada Apa dengan Cinta? (2002), iklan ini berhasil meraih banyak perhatian khalayak dan mendorong banyak pihak memanfaatkannya dalam bentuk video parodi, meme, atau bandwagon branding. 
Pada akhirnya, melihat antusiasme khalayak, euforia ini mendorong sang penulis cerita film Ada Apa dengan Cinta? (2002), yaitu Mira Lesmana berniat untuk memproduksi sekuel film Ada Apa dengan Cinta? (2002). Ini dapat dilihat dari cuitannya di akun Twitter miliknya pada 11 November 2014 atau lima hari setelah penayangan perdana di akun Youtube Line Indonesia.

\section{Institusional}

Melalui iklan ini dipahami bahwa Line berupaya menggantikan posisi telepon konvensional dengan free call, SMS dengan chat dan voice message, aplikasi berbagi foto dengan photo sharing, aplikasi online shop dengan Line Shopping, aplikasi pembayaran dengan Line Pay, aplikasi pencari lowongan kerja dengan Line Jobs, aplikasi berita dengan Line Today, aplikasi pencarian salah satunya dengan Find Alumni, aplikasi permainan dengan Line Games, dan emoticon/emoji dengan sticker. Hampir semua fitur yang dimiliki aplikasi lain dicoba untuk digabungkan dalam satu aplikasi. Dengan kata lain, Line berusaha menguasai pasar aplikasi lain dengan penggabungan salah satunya melalui iklan tersebut. Ini dipertegas dengan ungkapan Eva Martha Rahayu bahwa Line memposisikan dirinya sebagai Life Platform, yakni tidak sekedar instant messaging, tetapi mampu melengkapi hidup. Maka dari itu, Line dilengkapi fitur atau layanan menarik, seperti timeline, official account, sticker, konten, dll. (Rahayu, 2015)

Selanjutnya, penggunaan Youtube sebagai media penayangan iklan tersebut karena jumlah pengguna Youtube mengalami peningkatan signifikan pada kuartal ketiga tahun 2014, yaitu 130 persen. Selain itu, Youtube memiliki banyak kelebihan, satunya video dapat dimonetize/diuangkan. Baik itu pihak Line, Miles Production, maupun Youtube sama-sama mendapatkan keuntungan yang tak sedikit. Pihak Line mendapatkan keuntungan dari monetization Youtube, data demografi khalayak, pembayaran dari pengiklan di aplikasi Line, dan calon konsumen yang terjaring. Kemudian, pihak Miles Production memperoleh keuntungan dari monetization franchise film Ada Apa dengan Cinta? (2002) dan dampak masif dari penyebaran iklan berupa antusiasme khalayak terhadap sekuel film tersebut. Terakhir, pihak Youtube memperoleh keuntungan berupa kepercayaan perusahaan baru untuk memasang iklan, pembayaran pemasang iklan, dan kepercayaan khalayak.

\section{Sosial}

Sejak dulu, khalayak Indonesia dikenal dengan kegemarannya berkumpul atau bersosialisasi. Kegemaran ini pun tercermin dalam falsafah budaya Jawa, "Mangan ora mangan sing penting ngumpul". Sekalipun saat ini intensitas berkumpul secara langsung berkurang tetapi kebiasaan tersebut dapat dipenuhi dengan teknologi komunikasi yang saling terhubung. Selain senang bersosialisasi, konsumen Indonesia juga "suka ikut-ikutan". Konsumen Indonesia mudah dipengaruhi oleh public figure misalnya selebriti. Kedua kebiasaan inilah yang akhirnya menentukan arah yang digunakan Line dalam mengonstruksi wacana di dalam iklan tersebut.

Di samping kegemarannya bersosialisasi dan "suka ikut-ikutan", tanpa memandang generasi $\mathrm{Z}$ dan milenials, sejak dulu khalayak Indonesia memang dikenal konsumtif. Bahkan, perilaku konsumtif tidak hanya dilakukan oleh khalayak kelas sosial ekonomi menengah ke atas, melainkan juga menengah ke bawah. Tanpa disadari khalayak yang menonton iklan tersebut pun melakukan aktivitas konsumsi media berupa pengalaman dengan mengeluarkan sejumlah uang dan meluangkan waktu. Pada dasarnya, nostalgia selalu terkait erat dengan hal yang bersifat positif atau menyenangkan. Nostalgia cenderung berkaitan dengan kesenangan secara umum, sikap positif terhadap benda (orang, tempat, harta) yang biasanya (popular, modis) ketika seseorang masih muda (di awal usia dewasa, di masa remaja, di masa kanak-kanak). Meskipun nostalgia dipandang sebagai sesuatu yang positif, tetapi realitanya, nostalgia juga memunculkan efek negatif, yaitu perasaan sedih karena masa lalu yang indah tidak terulang di masa sekarang. Nostalgia biasanya dimunculkan dengan berbagai stimulus yang berkaitan dengan masa lalu. Stimulus dapat berupa tulisan visual, audio, bahkan bebauan, melalui berbagai macam medium, misalnya iklan.

Kecenderungan menggunakan nostalgia di dalam iklan didasarkan pada ketidakpastian 
ekonomi, familiarity, dan dampak yang ditimbulkan nostalgia yang identik dengan momen menyenangkan lebih dapat diterima oleh khalayak. Dapat ditarik kesimpulan bahwa iklaniklan yang sifatnya nostalgia membawa beberapa pemikiran kepada penerima iklan tersebut, seperti kenangan masa indah saat kecil, kenangan yang sulit dilupakan, hal-hal yang mengingatkan pada masa lalu, serta keinginan untuk kembali bermain bersama teman-teman kecil dulu. Secara garis besar strategi marketing melalui nostalgia dapat membawa efek yang positif tentang masa lalu. Hal ini secara otomatis berdampak positif terhadap konsumen dan akan menguntungkan pihak produsen. (Nugraha, 2017)

\section{Penutup}

Setelah melalui berbagai proses analisis sebelumnya, dapat ditarik kesimpulan bahwa pengadaptasian film Ada Apa dengan Cinta? (2002) yang dilakukan Line sesungguhnya merupakan upaya dalam mengonstruksi wacana nostalgia yang bermuara pada wacana ekonomi kapitalis, yaitu meraih keuntungan sebesarbesarnya. Selain itu, pengadaptasian tersebut dipandang sebagai upaya yang dilakukan Line untuk meminimalisir kegagalan promosi karena penggemar franchise film pertama Ada Apa dengan Cinta? (2002) yang berumur 27-37 tahun pada 2014 masih ada dan jumlahnya cukup besar.

Melalui pengadaptasian film tersebut, sesungguhnya Line tengah berusaha mendekatkan diri kepada khalayak Indonesia dengan menjadi bagian dari sejarah perfilman Indonesia dan memposisikan dirinya sebagai suatu kebutuhan dan gaya hidup bagi khalayak Indonesia. Selain itu, dengan menghadirkan fitur Find Alumni melalui iklan tersebut, Line berusaha mendekatkan khalayak Indonesia baik dengan khalayak lain maupun dengan pihak Line. Ini sejalan dengan tagline yang diusung Line, yaitu "Closing The Distance". Melalui penelitian ini diharapkan karya desain komunikasi visual di masa yang akan datang tidak hanya berhenti pada nilai fungsi dan estetis semata, melainkan lebih dari itu. Karya desain komunikasi visual harus mampu menorehkan sejarah sehingga tidak hanya berhenti pada sanjungan tetapi juga dapat dikenang banyak orang.

\section{Daftar Pustaka}

Eisenberg, M. (2011). ShapeShifter: Are Short Films the Future of Advertising?,. Retrieved September 14, 2017, from https://screenrant.com/shapeshifter-audicommercial-advertising-short-films

Eriyanto. (2011). Analisis Wacana Pengantar Analisis Teks Media. Yogyakarta: LKIS.

Fairclough, N. (1995). Critical Discource Analysis: The Critical Study of Language,. New York: Longman Publishing.

Ibrahim, I. S. (2007). Budaya Populer Sebagai Komunikasi. Yogyakarta: Jalasutra.

Nugraha, A. (2017). Nostalgia Strategi Marketing Perfilman Terkini. Retrieved from https:// id.linkedin.com/pulse/nostalgia-strategimarketing-dalam-dunia-perfilman-terkininugraha

Perdana, J. (2015). "Line: Manfaatkan Keterikatan Emosi Remaja Era 2000”,. Majalah Marketeers.

Rahayu, E. M. (2015). Gebrakan Line di Jagat Instant Messaging di Indonesia. Retrieved from https://swa.co.id/swa/headline/ gebrakan-line-di-jagat-instant-messagingindonesia

Williamson, J. (2007). Decoding Advertisements. Yogyakarta \& Bandung: Jalasutra. 